International Journal of English Literature and Social Sciences
Vol-6, Issue-2; Mar-Apr, 2021
Journal Home Page Available: https://ijels.com/
Journal DOI: $10.22161 /$ ijels

\title{
Ecologies of Pain in Bessie Head's When Rain Clouds
}

\section{Gather}

\author{
Mary Louisa Cappelli, MFA, JD, PhD
}

Orchid ID: 0000-0002-0419-9411

Nevada State College, Nevada, United States

Received: 18 Jan 2021; Received in revised form: 19 Mar 2021; Accepted: 03 Apr 2021; Available online: 27 Apr 2021 (C2021 The Author(s). Published by Infogain Publication. This is an open access article under the CC BY license (https://creativecommons.org/licenses/by/4.0/).

\begin{abstract}
Bessie Head's first novel, When Rain Clouds Gather, is perhaps one of her most ethico-political narratives to examine the introduction of modern capitalism and patriarchal science against the haunting spectral of traditional tribal systems in pre-Independence Botswana. Set in Golema Mmidi, which ironically translates to "grow crops," Head provides a detailed historical trajectory of how the imposition of agribusiness development projects onto traditional pastoral livelihoods devoured traditional tribal structures and ecosystems. In this essay, I examine how the implementation of modernized agricultural technology supplanted the collective relationship of subsistence farming, kinship systems, and cattle herding. I argue that When Rain Clouds Gather offers an interdisciplinary space for probing ecologies of pain in which scientific agribusiness projects have violently separated humanity from nature and rendered 63 percent of the Botswana's population food insecure.
\end{abstract}

Keywords-Bessie Head, Botswana, modern capitalism, ecological apartheid, ecological genocide, rural marginalization, sustainable agriculture, food insecurity, ecofeminism, agribusiness, postcolonial literature, African literature, When Rain Clouds Gather.

\section{INTRODUCTION}

Bessie Head's first novel, When Rain Clouds Gather, is perhaps one of her most ethico-political narratives to examine the introduction of modern capitalism and patriarchal science against the haunting spectral of traditional tribal systems in pre-Independence Botswana, a Bechuanaland Protectorate, which won its independence in 1966. ${ }^{\text {i }}$ Set in Golema Mmidi, which ironically translates to "grow crops," Head immediately sets the ideological tension between capitalist agricultural and traditional pastoral livelihoods providing a detailed model of how the merging of these systems produced intensive capitalist development by recruiting labor from traditional agricultural structures and supplanting the collective relationship of subsistence farming, kinship systems, and cattle herding with cash crops and individual wage incentives.

Prior to the arrival of the British, tribal people adapted to the conditions of their landscape by living nomadic lives and migrating with their cattle. The introduction of villagization processes created permanent settlement pockets of originally nomadic pastoralists in villages like Golema Mmidi. Here, agricultural livelihoods and pastoral life merge into a complicated village of "individuals who had fled there to escape the tragedies of life" forcing them to make the land the central part of their existence (Head 16). Head throws a monkey wrench into this fragile world of collapsing socio-political structures and ecosystems with Gilbert's introduction of modern capitalism and scientific patriarchy. While many critics contend that Head's When Rain Clouds Gather suggests that the agricultural collaboration between traditional knowledge and modern European agriculture represents a "healing gesture" of "humanitarian progress," I read this text against the grain of prior criticism (Highfield 2010; Fielding 2003; Margree, Garrett 1999; Ogungbesan, 1979). Although I am cognizant that I appropriate Head's text for what Mary Lederer (2019) refers to as my "own purposes and ideologies," I argue the necessity of examining Head's fiction as essential 
ethnographic documentation for understanding the present state of environmental affairs (135). I proffer that Head's text must be read as a parable of how imperial do-good projects and Western ideology trammeled Botswana's ecosystems (Lederer 78). Head's literary discourse foreshadows a global resource race that devastated Africa's ecosystems and subsistence communities in a narrative that demonstrates a deeper struggle for food security. In this interrogation, I employ an interdisciplinary ecofeminist subsistence perspective that scrutinizes gender relations within indigenous systems, to investigate the interconnections of colonialism, capitalism, and development. This interdisciplinary approach "cannot be explained through traditional literary approaches" (Nazareth 221).

Informed by the necessity of biodiversity for the sustainability of reproductive life, When Rain Clouds Gather, moreover, offers a productive ground for investigating how women's traditional reproductive and productive livelihoods have been disrupted by the collusion of traditional patriarchy and modern scientific patriarchal projects. It is at this juncture of Botswana's immersion into a globalizing modernity that demands an African ecofeminist perspective rooted in concerns for Tswana society, culture, and its ecosystems (Camineo-Santangelo, 2007; Lionnet, 2000; Lederer, 2014; Murphy 2013; Nixon, 2011; Vital, 2008; Wangari, 2003, 2006, 2009). Head's literary place based narrative creates an interdisciplinary space for probing the "slow violence" of ecological apartheid. ${ }^{\text {ii }}$

Within this landscape, I problematize mal-development projects aimed at addressing Golema Mmidi's environmental and reproductive collapse and consider three interrelated concerns. The first concerns the imposition of a mechanistic worldview on indigenous subsistence livelihoods and the subsuming of traditional subsistence systems into dependent capitalist formations. The second concerns the manipulation of traditional land tenure systems, the introduction of cooperative capitalist enterprise in the production of monoculture cash crops, and, more importantly, the deployment and appropriation of women's labor and "cradle know how" to sustain the production of these exchange commodities (Serowe 180). The third concerns the introduction of modern interventionist technologies in the form of "scientific production of highgrade beef," "imported seed grass," and other "imported drought-resistant grasses," and "tractors," "planters, harrows, and cultivators."iii A corollary concern to this interventionist technology is the traumatic "dynamiting," "damming" and "enclosing" of Golema Mmidi's ecosystems. In this discussion, I extend Caruth's analysis of trauma theory to the violent wounds inflicted on Golema
Mmidi's landscape. While Gilbert's action at first glance might seem to appear as innocuous activities in the interest of progress, their "delayed appearance and its belated address" is a "wound that cries out" throughout across the landscape (Carouth 4). According to Cathy Carouth, "what returns to the victim, these stories tell us, is not only the reality of the violent event but also the reality of the way that its violence has not yet been fully known" (6). It is this violent trauma that continues to "haunt" Botswana's ecosystems leading to what Ken Saro-Wiwa (1992) refers to as "ecological genocide" (9).

Head makes "the apparent appear" tangible and discernable - a place to examine scientific violations based on the logic of progress and development that continues to separate humanity from nature (Nixon 15). ${ }^{\text {iv }}$ Specifically, Golema Mmidi provides a historical landscape to discuss the significance of the interrelationship between Tswana people and their ecosystems and the disruption of these relations by western imperialist projects (Loflin 1998; Murphy 2013).

\section{GOLEMA MMIDI}

Influenced by her five-month stay on the Radisele Farm, which in her letter of February 10, 1967 narrates that it was started by "Tshekedi and Guy Clutton-Brock," Head contrives to cnstruct Golema Mmidi as a hopeful place against the stifling environment of South African apartheid politics (Vigne 50). It is within this space that Head positions her protagonist spiritual idealist Makhaya (Mack) who lives within the triple bind of his Zulu tribal past, his diasporic migrant status in Botswana, and the influence of Western thought - all the while struggling with spiritual dilemmas that haunt his ancestral soul. Having fled South Africa after serving two years in prison for plans to blow up a power plant, Mack seeks refuge in Barolong, Botswana because "he could not marry and have children in a country where black men were called 'boy and 'dog' and kaffir'” (Head 10). Head immediately sets up the importance of what Maxine Sample refers to as man's desire for an "affective bond between person and place" (28). Mack flees from a collapsing political system to a collapsing ecosystem - in a search for a sense of belonging and reproductive possibilities (Sample 28). ${ }^{v}$ Although Mack says, "It's not so much what I'm running away from," it becomes quite clear that he desires a fertile ground to produce "a wife and children" free of both customs and apartheid politics (Head 26). After leaving his "mother in a state of complete collapse," Mack desired to cut the ancestral umbilical cord to a tribal past "that was mentally and spiritually dead through the constant perpetuation of false beliefs" (Head 10). He disdained concepts of tribalism 
and "the mentality of the old hag that ruined a whole continent-some sort of clinging, ancestral, tribal belief that a man was nothing more than a groveling sex organ" (Head 9). This contempt for traditional belief systems affirms his initial renunciation from his tribal roots $($ Head 9$){ }^{\mathrm{vi}}$

Instead of finding a flourishing Eden, Mack encounters a collapsing landscape of malnourished children who die from hunger "with their knees cramped up to their chins" (Head 118) and "where even the trees were dying from the roots upward" (Head 164). Head suggests that the withering kinship tree of "the royal line of headmen or chiefs," which once "stretched way back time" to where "a single family often made a nation" has been subjected to myriad traditional, colonial, and capitalist destructive impositions (Head, Serowe 71). Head's ecology of pain problematizes collapsing ecosystems within a particular cultural context and offers a "textual space" where the landscape "speaks, and reveals" itself (Lionnet).

In describing Paulina's tribal community Head describes it as once being "the most closely knit of all the tribal groupings, each one claiming at least a distant relationship to even the most insignificant member of the clan" (Head, Rain Clouds 70). In Serowe: Village of the Rain Wind, she observes how "in those days a single family made a nation" (Head 71). Sadly, this is no longer the case as Paulina's close knit "family structure began breaking down under the migratory labour system" in which men moved to urbanized areas to work in large companies where maintaining the correct accounting ledgers was privileged over family relations (Head, Rain Clouds 70). Head positions Paulina Sebesco's husband as a casualty of this system and who ultimately "hanged himself from a tree in the yard" (Head 71). Paulina and her two children are later dispossessed by a "certain large company" for whom her husband worked (Head 71). Both Paulina and her husband's lives are disrupted by their encounter with colonial violence and what Cajetan Iheka refers to "as the inscription of trauma arising from such violence" (33).

On the other hand, traditional epistemologies have also led to destructive tendencies as in the case of the secretive and secluded Mma-Baloi who was allegedly accused of being a witch because of the "surprising number of child deaths in the village of Bodibeng" (Head 47). To the villagers, the deaths of the children and Mma-Baloi's strange behavior were connected. After the postmortem investigation of the body of a young woman, it is discovered that she "had died of a septic womb due to having procured an abortion with a hooked and unsterilized instrument" (Head 47). According to the report, "the septic condition of the womb had been of three months' duration" (Head 47). ${ }^{\text {vii }}$ In this case, we witness the underlying despair of women living under depleting traditional patriarchal systems. Faced with birthing another child into extreme conditions in which death by starvation is an ordinary occurrence, women choose to empty their wombs as a form of reproductive survival.

Mack welcomes "Gilbert's scientific perspective" as an alternative to these "retrogressive" traditional systems of destructive ancestral beliefs (Head 130). "It was he, Makhaya, the individual, who was seeking his own living life because he was fearful of the living death a man could be born into" (Head 131). Embracing similar notions of individualism as Gilbert, Mack recognizes his place in the collective suffering of mankind as well as "his own separateness" from humanity (Head 75). Head situates Mack within this contested space of socialism and capitalism, subsistence livelihoods and scientific agroimprovements, tribalism and nationalism. She is meticulous to point out the competing ideologies in which "sons of chiefs, and "sons of slaves" compete amidst attacks of "imperialists and neo-colonists who were still skillfully manipulating the affairs of an oppressed people" (Head 58). Gathering missionaries, NGOs, and political dung slinging from above and below, Head invokes the "second scramble for Africa" under the direction of patriarchy and subordinate assistance of her strong female characters (who as usual) perform all the dung mixing (Head 59).

Dinorego's wise declaration that "most of the trouble is caused by people from outside" doesn't stop Head's outsiders from collaborative co-operative enterprise. South African outsider Mack dedicates his life to joining forces with outsider English agriculturalist Gilbert, another robust "intellectual" head bent on improving the conditions of the impoverished by introducing modern agricultural methods. Described as a "giant" and "dressed in the stereotypical "short khaki pants" of a British do-gooder, Gilbert arrives on the African landscape "seeking some new challenge" from his previous life in England (Head 23). Head roughly bases Gilbert on Vernon Gibberd who she describes as a "big agricultural man" who she worked with at the Bamangwato Development Farm (Vigne 220). She claims much of her agricultural knowledge is informed by working with Gibberd and his agricultural papers (Vigne 221).

After visiting three years prior on a "student travel grant," Gilbert is allegedly inspired to take on the Kipling's "White Man's Burden" and "work another's gain" by venturing into a career in "agricultural development and improved techniques of food production" (Head 17). Perhaps, the connection between student overseas travel to the Global South and the implementation of agricultural assistance activities is one of the reasons why When Rain Clouds Gather is on the Peace Corps 2014 Botswana Welcome Book so that other white aspiring do-gooder Gilberts can too contribute their eco-Imperial knowledge 
"at the service of the country" (Head 18). ${ }^{\text {viii }}$ Gilbert—"the gigantic storage house of facts and figures and plans and intuitive judgments and impressions"- -speaks to Mack's longing for an ordered world where the sun can shine benevolence on the poor and forgotten (Head 76). For Mack, Gilbert's enlightenment reason can do more than a sun that failed to reach the poor and "shut-away worlds where the sunlight never penetrated, haunted worlds, full of mistrust and hate" (Head 76).

Makhaya considers Gilbert's mind to be similar to a "loud humming" stop-watch whose spinning "wheels kept on turning at such a fast pace" that Makhaya becomes dumbstruck into serving Gilbert's mechanistic process of "environmentally embedded violence" (Nixon 8). Carolyn Merchant proffers that the mechanistic worldview "arose with the support of early capitalism," replacing Renaissance concepts of "nature as a living organism with nurturing earth at the center" with a Baconian "ethic of domination" (11). Gilbert's scientific patriarchal machinations are rooted in this "mechanistic science of the seventeenth century" (Merchant 70). Gilbert's ethical intentions to employ the natural habitat of Golema Mmidi at the service of commodity production of Turkish tobacco represents one of the "central tenets" of commercial capitalism -the use of nature as commodity (Merchant, Vatn, 2000; Clay, 2004; Nixon 2011). His actions, moreover, demonstrate how "imposed official landscapes typically discount spiritualized vernacular landscapes, severing webs of accumulated cultural meaning and treating the landscape as if it were uninhabited by the living, the unborn, and the animate deceased" (Nixon 17). Head's geological time period is set in the Anthropocene Epoch where we, as readers, are privy to Gilbert's actions its devastating impact on Botswana's ecosystems (Robin, 2008). Gilbert's mechanistic view runs contrary to the existing subsistence economy, which he blames for the dire conditions and ecological destruction, contending that "the people engaged in subsistence farming were using primitive techniques that ruined the land" (Head 17). Yet, Head observes that people battling to survive on the "barest necessities" is as old as the land itself (Head, Serowe ix). She reveals this contested landscape as "a laboratory for studying the clash between modern scientific methods and technologies and traditional practices" (Highfield 104). For Gilbert, "nature, the human body, and animals all could be described, repaired, and controlled, as could the parts of a machine, by a separate human mind acting accordant to natural laws" (Merchant 71).

Head also reinforces imperial notions that social reform and environmental "good" can only come from outsiders. As Huma Ibrahim writes:

It is not just with the arrogance of an exile that
Head can claim that the outsider brings reforms to a society; here the assumption is that this change is desirable to the natives. Change, filtered down from the Westernized locals, comes back to haunt developing countries because the patterns of change have been determined by capitalistindustrialist interests, which seem, at best, only marginally relevant to the postcolonial situation, and at worst they destroy indigenous economies, cultures, and peoples. (69)

Within Gilbert's scientific mindset, he cannot understand the indigenous subsistence perspective based on nature's systems of reproduction and renewability in which food security is harvested by women the color of the soil (Head 118). Moreover, Gilbert recognizes that if he is to implement his foreign NGO-backed "grand scheme" of cooperative enterprise, he must enlist Makhaya, "someone with the necessary mental and emotional alienation from tribalism to help him accomplish what he had in mind" (Head 24). Since Makhaya has ties to the indigenous Zulu tribe, he will be able to assist Gilbert's ability to manipulate "the complexity of the land tenure system," which he believed "was a hindrance to agricultural progress" (Head 32). Because of Gilbert's attack on the traditional land tenure system, which was "designed to protect the interests of the poor and to prevent the land from falling into the hands of a few rich people" he found himself flailing in the vortex of a "violent storm" of ideology with Chief Matenge who is dead set on maintaining traditional land tenure holdings (Head 32).

\section{TRADITIONAL LAND HOLDING}

Head's conflicting anti-tribalism attitude surfaces in her depiction of the greedy Matenge; yet, Matenge, in all his psychological complexity, sees land as a key social component and unifying factor that nourishes indigenous identity and spiritual connections to each other and their village community. Under the traditional system, "ownership of the land was vested in the tribe as a whole" and "no man could claim that he had purchased a plot of tribal land and anyone who asked was merely allocated a portion free of charge by a chief" (Head 32). Gilbert must rhetorically backtrack and qualify his proposition about the traditional tribal land tenure system by declaring that "cooperative organization was similar to communal ownership of land" (Head 32). The clash between Gilbert and Matenge over customary land usage offers an inquisitive space for understanding tribal land policies and issues within Golema Mmidi's changing landscape. ${ }^{i x}$ Within this dynamic exists the inner tribal conflict between Chief Matenge, who tries to preserve traditional customs and his position within the 
tribal community. The villagers of Golema Mmidi must adapt, accommodate, and, or, dismiss the environmental, technological, and ideological forces challenging their community. ${ }^{\mathrm{x}}$ Incapable of suppressing the changing socioeconomic and political forces in Golema Mmidi and other "outsider" voices inhabiting this landscape, Matenge like Chinua Achebe's Okonkwo kills himself.

The privatization of communal land holdings and increased technological agricultural development has had a devastating impact on sustainable livelihoods rendering tribal populations vulnerable to hunger and collapsing kinship structures. Gilbert understands that "exploitable resources could be profitability incorporated into metropolitan capitalist structures and the unincorporated, disposable remainder" (Nixon 71).Although Gilbert masks his intention in do-good rhetoric of cooperative enterprise, his economic model is shaped by capitalist patriarchy and strategically rooted in the economics of development and bottom line productivity, which has led to growing economic disparities and reproductive inequities throughout the Global South. The key assumptions of his "grand scheme" appears to be based on individualistic motivations of self-interest disruptive to indigenous notions of community and traditional notions of place. Hence, development projects for most indigenous peoples threaten survival itself.

The implementation of Gilbert's agricultural development plans not only foreshadows a masculinist shift of farming as a means of generating profits, but "resource imperialism" that commands Botswana "to maintain the unsustainable consumer appetites" of the Global North (Nixon 22).Gilbert's logocentric ethic further motivates him to want to "show everyone else just how quickly things could really change, how ordinary people could get up and do things for themselves and produce enough for their needs and have some left over for sale" (Head 182). According to Gilbert:

Large chunks of the year went by just watching the sunrise and sunset, and who knew too if the subsistence man did not prefer it this way? It was easy, almost comparable to the life of the idle rich, except that the poor man starved the year round. Not in Africa had the outcry been raised, but in the well-fed countries. Something had to be done about the man who lived on subsistence agriculture, because without his co-operation the world could not be properly fed. Gilbert took this a little further. Voices had to be raised in Africa too, and they had to come from men like Makhaya who deeply craved a better life, not only for themselves, but for all these thousands and thousands of people who walked around with no shoes. (Head 118)

Herein, lies another contested battleground between indigenous customs and modernized agriculture in a village with a predominantly cattle existential focus - which leads to another concern: the introduction of monocultural cash crops. Gilbert, like today's international farming conglomerates represents patriarchal science, patriarchal capitalism, and the masculinization of traditional agricultural practices. ${ }^{x i}$ The result is an agricultural war against local production and local consumption.

\section{MONOCULTURE CASH CROPS -THE SEEDS OF BOTSWANA'S HUNGER CRISIS}

Gilbert arrives in Botswana with a similar "destiny of every white person who comes to Africa" toconquer-"or at least survive-the desert" (Lederer 52). Gilbert's political economy joins two fundamental concepts-capital accumulation and reproduction. In Head's man vs. nature plot, Gilbert must transform Golema Mmidi's ecosystems into a paradigm for profit and make it desirable to grow

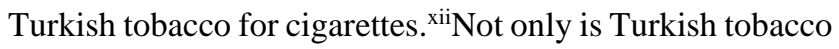
conducive to the bioregion, but "very good cash crop too, and if everyone in Golema Mmidi grows a bit and we market it co-operatively - why, we'll all be rich in no time" (my emphasis) (Head 54). Unfortunately, tobacco is not edible.

Gilbert perceives growth and its intersected means of production as driven by profits, expansion of the market, gender division of labor, and forces of production. Capital accumulation depends on reproduction, which includes biological reproduction of the labor force and social reproduction of its male privileged social systems. Gilbert's scheme is not gender neutral as while Paulina is cast as stage manager of this production team, she is not an equal partner in Gilbert's "development" enterprise. Rather, his system, which on the surface appears to provide a new form of food and water security and female liberation intensifies inequalities, placing women and nature in subordinate positions at each different level of production. Gilbert felt that "he had stumbled onto one of the major blockages to agricultural progress" the failure to incorporate women into development plans (Head 28). Although women "were the traditional tillers of the earth, not the men," it was the men who were trained in biotechnical destruction in "the use of pesticides and fertilizers, and the production of cash crops" (Head 29). Gilbert's get "rich" production scheme, involves the dismantling of these traditional kinship arrangements with the gendered animation of women to cultivate, cure, and dry the tobacco in addition to hauling the mud to construct the storing sheds (Head 94). At this juncture, we 
witness one of the first instances of violence against women's subsistence livelihoods by the seduction and integration of women's economy into his plan. Enlisting women to engage in the rape of nature, the rape of their own livelihoods is an egregious violation against ecology and humanity as a whole. Current literature on the shift from sustainable agriculture to agricultural commercialization documents how agricultural modernization threatens family relations, food security and other traditional bonds to the environment-negative consequences especially felt by women (Murphy 212).

Agri-technocrat Gilbert has his own visionary ethics of obtaining "paradise," and equips the women with "pickaxes and spades" to scrape out the foundation for the many sheds that are needed to dry the tobacco. Head portrays Gilbert's animated female soldiers stepping in line to the patriarchal development tune of environmental destruction dreaming of a Gilbert or Makhaya to save them from their plights (Head 103). The very idea of women switching from subsistence crops needed to feed their families to the single production of Turkish cash crops to sell at the market under the direction of a white male scientist highlights perhaps one of the major concerns of indigenous farmers - food security. Crop diversity is essential in maintaining bio diverse ecosystems and the production of edible food supplies. Studies have shown that Gilbert's maximization of tobacco production over other food crops will impair the "natural integrity of the resource base necessary for food production by eroding biological diversity, promoting pest and disease infestation, depleting soil fertility, and requiring massive application of harmful agrochemicals" (Gonzalez 432). ${ }^{\text {xii }}$ Contrary to Gilbert's speculations, monocultures not only instigate collapse of the ecosystem, cash production of monocrops have exasperated sustainable livelihoods by undermining basic food security. Gilbert realizes that to consolidate patriarchal power between European men, Tswana elders, tribal leaders and development officials, he must integrate women to support their accumulation and growth in the capitalist sector. His cash crop production schemes to move to Turkish tobacco disrupts women's roles as providers of subsistence crops for family sustenance and channels food production to commodity production for export. His cash-cropping scheme guised as a "colonial discourse of betterment" entails the "recasting of gender," extraction of land and labor from mothers as well as the enticements to mothers who will be able to buy commodities with generated income (Mackenzie 27). Certainly, Gilbert recognizes that it is the women who have in the past engaged in small-scale subsistence farming, and like today's international farming conglomerates strategically enlist women's assistance to do all the agricultural dirty work, including the building of seed storage huts under the supervision of Mack's love interest, headstrong Paulina.

Again, we witness how for many African women, the discourses of labor and reproduction are interdependent discourses. Gilbert's agricultural production schemes demonstrates how "the politics of food is gendered at multiple levels" (Shiva, Staying Alive xvi).Food insecurity is gendered. Tribal women have deeply suffered in the tripartite chokehold of colonial, neocolonial, and neoliberal resource and land grabbing. As evidenced in Head's narrative, women continue to be the "primary tillers of the land under increasingly inclement circumstances, including soil erosion and the stripping of the forests" cooperating in in their own demise (Nixon 140).

The women in Head's Golemi are cast "like Frankenstein monsters, only animated by the white man for his own needs" in this case it's development guised as “economic growth" (Head 128). Head's female characters take up Gilbert's vision of "Turkish Tobacco" harvesting in which the influential Paulina Sebesco and Mma-Millipede are enlisted to persuade other women to "attend classes" on how to "cultivate" in their own yard[s]..."(Head 101). The dependence on male saviors in this story seems to legitimate a political, social, and economic dependence on patriarchy. Gilbert and Mack replace the Tswana kinship system with a European version of dikgosi royals and "heroes." Their grand entrances suggest a fusion of patriarchal privilege in a narrative in which men waltz on stage in heroic proportions with theatrical displays of great determination and optimism. Similar to the men Head idolized-Khama the Great (1875-1923), Tshekedi Khama (1926-59), and Patrick Van Rensburg (1963-) — her fictional characters make "great gestures" to "change the world" (Head, Serowe xiv). While Head's gestures acknowledge "when the land can be managed, the people will no longer be the victims either of nature or the grandmasters who wield power for their own benefit," she unfortunately did not foresee the imperative interconnection of ecosystems and ecosystem people (Fielding 20). She does not acknowledge the imperial impositions that have Gilbert scrambling around to correct the devastation released by his British ancestors.

As Michael Glantz writes, "Drought follows the plow" (107). In this case, Gilbert's machinations to cultivate tobacco at the expense of biodiverse food crops added to climate fluctuations. Head discounts deleterious effects of Western projects that had rendered the land lifeless and discounts the value of traditional knowledge and sustainable agricultural practices to protect its ecosystems; instead, "her model relies entirely on the imported European knowledge of men like Gunner and Balfour" (Highfield 112). 
Head's account of the masculinization of farming and the manipulation of Golema Mmidi's crop farming foreshadows the shift from local control crops raised on women's traditional knowledge and productivity to monocrop commodities driven by transnational patriarchs, the global market, and corporate monopolies. For what Gilbert perceives as cooperative agricultural development is in reproductive terms vastly destructive production. Not only is crop diversity usurped by inedible monocrop tobacco production, but also women's traditional skills of maintaining subsistence food security are supplanted by crop cash production. ${ }^{\text {xiv } ~ " W h e n ~ t h e s e ~ r e s o u r c e s ~ a r e ~ a l r e a d y ~}$ being used by nature to maintain her production of renewable resources and by women for sustenance and livelihood, their diversion to the market economy generates a scarcity condition for ecological stability and creates new forms of poverty for women" (Shiva, Staying Alive 9). The violence intrinsic of mono-cash-crop commodity production is violence against women's reproductive and productive livelihoods and "nature's biodiversity." Shiva is correct in her assessment on food security: "When the household and community are food-secure, the girl child is food-secure" (Shiva, Staying Alive xvi).

In a place "where people ought not to live" and sustainable sources are scarce, people and cattle sulk across the landscape together searching for food and water sources to survive (Head 19). In Head's Golema Mmidi's we bear witness to a "slow violence" that is "exponential" where contemporary life in Botswana is a result of years of resource grabbing and ecological degradation (Nixon 4). For women like Paulina, "cattle were all that stood between her children and outright starvation" (Head 136). Makhaya's suggestion to Paulina "to sell the damn beasts" upsets Paulina's existential world in which the belief persists that a "Motswana without any cattle might as well be dead" (Head 137). In Head's Golemi, cattle begin to drop like flies, one man's herd reduced from 200 to 80 . Head situates Gilbert's accompanying proposal for "scientific production of high-grade" as the antidote for "low grade beef" on a perishing landscape precipitated by "uncontrolled grazing" (29). For Gilbert, "there was a serious reason for finding urgent solutions: the country was in the grip of a severe drought, which had already lasted five years and was becoming worse with each succeeding year" (Head 29). Gilbert's proposition for herd reduction incorporates a "corned beef" venture based on an "accelerated slaughter of emaciated beasts at the abattoir," which would then be "boiled down to corned beef" (Head 149). His plans to "beef up" the remaining cattle include the "latest development in fodder crops for cattle feed and silage-making and his own experiments with the natural grasses of Botswana and imported seed grass" (Head 149).
It is unclear whether in addition to imported seed grass, Gilbert also proposes a "drought-resistant type of grass seed," or if it is one in the same that is sown as he tries to judge "whether indigenous grasses or imported droughtresistant grasses would be best suited for cattle grazing" (Head 33). Regardless, his pursuit for drought resistant seeds extends to the "drought resistant millet seed," which is engineered to retain water in arid locations (Head 35). Although tribals prefer sorghum and maize to millet, and consider those who do eat it "inferior," Gilbert discounts traditional sustainable practices and engages in "intensive research" studies on millet production in contra-indication to traditional eating habits. According to Gilbert:

Yet fifteen thousand varieties of millet had been tested in the country, and the authorities had initially bred a type that could produce a crop in only three inches of rain, with a few most-needed advantages. Witchweed, which is a parasite that is germinated by and lives on the root of maize and sorghum plants, stunting their growth, was germinated by this type of millet as well, yet the plant remained unaffected by it. (Head 35)

Gilbert's scheme to introduce a genetically modified drought resistant seed situates him as a pioneer of Botswana's biotechnical Green Revolution. ${ }^{\mathrm{xv}}$ What Gilbert's "research" does not tell him is that the reproductive genetic engineering of millet seed has the potential of cross-contaminating other food crops disrupting Golema Mmidi's bio-diverse ecosystems and food security by introducing viruses and bacteria to existing food crops. "While increased food productivity is the argument used to promote genetic engineering, when the issue of potential adverse impacts on farmers is brought up, the biotechnology industry itself argues that genetic engineering does not lead to increased productivity" (Shiva, Making Peace 172). Patriarchal science and what Vandana Shiva refers to as the imposition of a "production boundary" has not only failed nature's ecosystems it has usurped and devastated women's reproductive livelihoods. What Gilbert, the vanguard of stress-responsive transgenic seed, cannot foresee is that "genetic engineering is thus not a reliable technology for drought tolerance" (Shiva, Making Peace 189).

Adding to the crisis is Gilbert's plan for disrupting the natural water cycle of Golema Mmidi, which entails a militarized strategy for creating a "network of boreholes and reservoirs," by damming and dynamiting the ecosystems into subservience (Head 108). As readers, we are privy to the deleterious activities that lead to soil degradation and the destruction of natural water tables. Gilbert's desire for constructing a "paradise" in his own image entails blasting "out with dynamite" large mud pits to be filled with 
"polythene and the sides to be supported with sandy, concrete-filled plastic" (Head 131). This will be used for collecting water. Juxtaposed against the destructive images of blasts and explosions, Makhaya ruminates on the interconnectedness of nature's innocent creatures as he witnesses "the soft juicy bodies of white ants, and thousands of birds" whose survival depended on "these juicy morsels" (Head 132). Paradoxically, while the cattle are dropping dead, the ants are still "soft and juicy," capable of maintaining their existence within the natural life cycle of its bioregion without Gilbert's masculinist irrigation and water management machinations. Of course, under his plans even the "soft and juicy" ants will be blasted to smithereens. According to George Perkins Marsh, this is just more substantive evidence of how hydrological projects "promote the accumulation of large tracts of land in the hands of single proprietors," thereby dismantling traditional land holdings. Here, we witness "the calamitous repercussions" played "out across a range of temporal scales" (Nixon 2). The activities "of clearing, tilling, and weeding fields together with those livestock impact in the near vicinity of settlements would have been highly visible but short-lived as they are today"(Kinahan 245).

Head ultimately constructs a paradigm where traditional patriarchy and capitalist patriarchy collude to impose production boundaries on Golema Mmidi lassoing the ecosystem into a traumatic slow death by extermination, while the romantic couples Makhaya and Paulina, Gilbert and Maria stare into each other's eyes for comfort behind their newly enclosed lives. In 1966 with Botswana's independence, government authorities wholeheartedly embraced foreign capital, which paved the way to increased exploitation of resources (diamonds), and an elite tourist industry. Operational farmer and headman Makatse Modikwa discloses to Head, "We built our own dams and our own boreholes - the central borehole in Serowe was paid for with our cattle and the water was free for a long time. Now we pay. Today, after all this hard work no rewards come to the people of Serowe" (Head, Serowe 112). While Seretse Khama declared in his 1969 speech that, Botswana did not gain its independence in order to create further divisions between "privileged town dwellers and toiling farmers," the divide between rich and poor is wider than ever (Vengroff 22). Similar to other political tactics of social relief and donation projects deployed to maintain local government control, Botswana's local government secures their power through helicopter droppings of relief packages at election time.

In this eco-apartheid of "fatherless children," and inequitable disparity of sustainable resources amongst indigenous peoples, lessons in survival are imperative for Head's females. Fatherless children translates to toil and labor for mothers and children who have to work in the place of the father. Sadly, Head's story is no different. Paulina's son is sent out to the furthest cattle post to earn much needed subsistence income and ends up dying of malnutrition during the drought — his death foretelling the collapse of "the cattle outpost economy," suggesting that certainly there must be some imperative to reimagine indigenous livelihoods in the Global South (BillingsleaBrown 90). His young tragedy mirrors the death of many children facing poverty and famine, a narrative literariness that demands attention to the vanishing peoples of the world who "confront turbo-capitalism's assaults on the resources" that preclude" or "shape their survival" (Nixon 42). In the end, resource grabbing goes hand in hand with environmental degradation and the death of the earth's remaining indigenous peoples. It is in the horror of the young boy's death that Makhaya realizes "that it was only people who could bring real reward of living, that it was only people who give love and happiness" (Head 158). In her January 14, 1969 letter to Randolph, Head observes: "The land was made holy by people's suffering. Subconsciously the same process is going on in South Africa. That land is being made holy by all the tears of the black man which have dropped on to the soul" (Vigne 75). Head constructs an ending that delves into the inescapable mysteries of life in which unbearable suffering leads to "something big" for those who can endure and love in spite of the unbearable weight of being (Vigne 74). These "giants of the soul" revision the future by connecting to those around them (Vigne 74). Similarly, Makhaya expresses Head's own realizations: "The white man was a spoke in a slow, churning wheel to make things move. The spoke is painful but only a saint accepts and knows this. The saint too often shuts his mouth, knowing life a little too deeply" (Vigne 130). If "progress" is the ultimate desire, Makhaya must silently step into its spinning machinery.

This is Head's enigma of life - death, beauty, genius, and loving captured in the ordinary humbleness of human connection (Vigne 74). Makhaya lives deeply, feels deeply, and too realizes his true humble commitment when he is told that "If you've left no treasures on this earth, what's there to hold onto except a terrible pity" (Head 177). These treasures of connection and belonging are the antidotes to human suffering. Head makes visible the unseen by making man and woman's connection to each other and to the environment a visible and treasure trove of life's affirming gifts and blessings. It is in Mack's resistance to the "hate making ideologies" that privilege resources in the hands of the few "while so many starved" that his compassion is awakened (Head 75).

Mack dedicates himself to this treasure trove working for Paulina, her children and the poverty-stricken village of 
Golema Mmidi. Head asks, "How else are the mighty to be pulled down from their seats except by the ordinary humble people?" (Vigne75). Makhaya summarily reduces global redistributive justice to one ethico-political strategy in which he recognizes God in himself and all mankind. In so doing, he is "obliged to live a noble life, where people can depend on him to be truthful in his dealings" (Vigne 91). It will be those wise and generous, those "people with no shoes," "who shall, one day, unexpectedly, inherit the earth" (Vigne 137).

While Head's Makhaya has developed a "generosity of soul and of mind," his psychological gymnastics in selfrealization has not awakened him to his own collusion with the patriarchal dominance of his interior and exterior landscape under the guise of "cooperative enterprise" (Rain Clouds 119). Three of Head's "chief horrors" were "totalitarianism, tribalism, and Marxist-Leninism" (Vigne 210). In When Rain Clouds Gather, she "works out" her own hypophoric question: "Do you think a leadership of unbridled capitalistic interest is more of a salvation to the country than a Marxist approach?"

\section{CONCLUSION}

In this essay, I have argued that Bessie Head's When Rain Clouds Gather provides a seminal interdisciplinary space to examine the catastrophic slow violence of what happens when tribal peoples are displaced from their ecosystems and their reproductive livelihoods in order to promote neoliberal agendas of progress and national development (Nixon 15). This historical lens for understanding the traumatic ecological events attests to why today in 2021, Botswana must import 90 percent of its food products to feed its population. Rising food prices and the Covid Pandemic have only worsened food insecurity amongst the rural and urban poor. While it exports high quality grass-fed beef and related cattle associated items (Figure 1), it must import basic food items as seen in Figure 2.

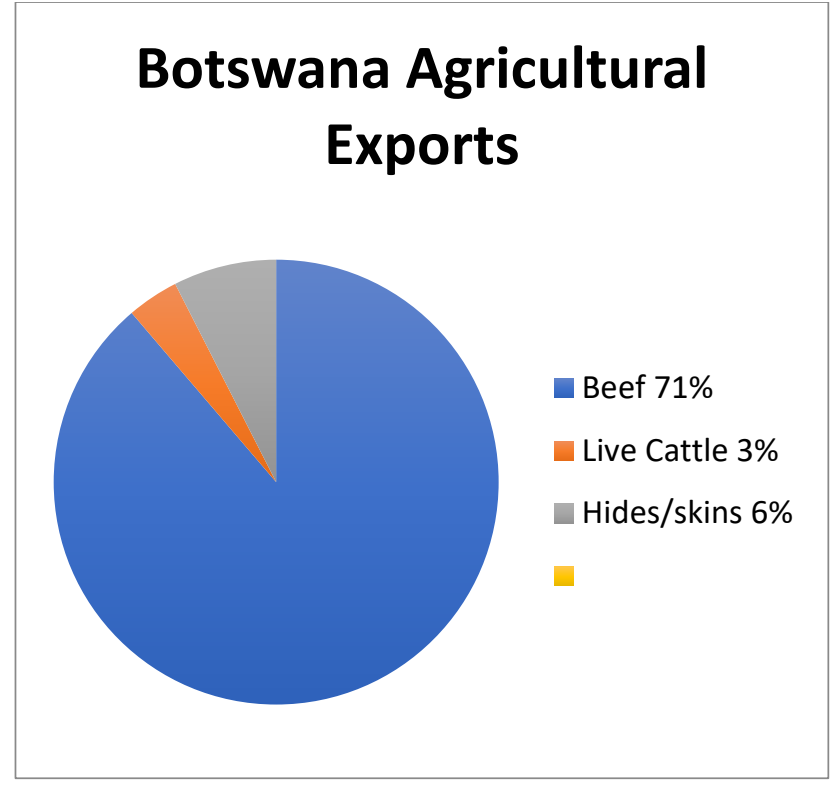

Fig.1: Agricultural Exports

\section{Agricultural Imports}

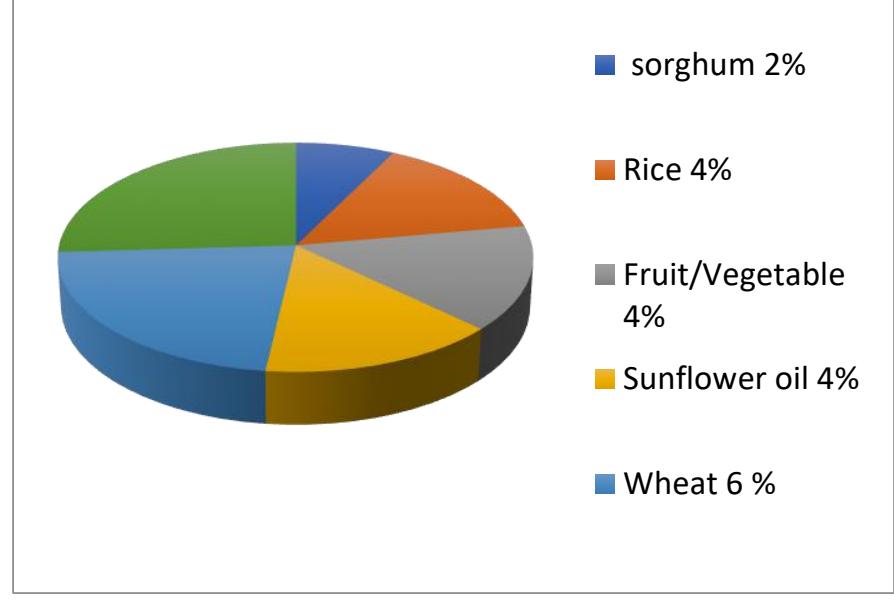

Fig.2: Agricultural imports.

Head's ethnographic fiction foreshadows how in the initial stages of mal-development projects, Botswana's sustainable economies were later usurped by transnational agricultural conglomerates thereby creating a country ripe for disaster philanthropy; Botswana now receives assistance from the Peace Corps, USAID, The International Money Fund, The World Bank, and other non-profit organizations. While Botswana is one of the largest beef exporters to the European market, its diamond market far exceeds its beef market in terms of generating revenue. Most of Botswana's diamonds are produced through a joint-venture/privatepublic partnership between the Botswana Government and De Beers a multinational mining company with offices in 
Canada and the US and the Botswana government. Whereas this relationship does benefit an elite few, during the timing of Head's writing, Botswana was one of the poorest nations in the world. Today, it is marked as 63 of the world's poorest nations. In spite of moving off the list of the top ten poorest countries on the planet, Botswana's people maintain one of the most unequal wealth distributions in the world. To make matters worse, in the 1980s, the Botswana government implemented a land-grabbing harassment campaign against its tribal communities to drive them away. In Gaborone the center of beef and diamond businesses the medium domestic income is just $\$ 2$ per day rendering 63 percent of the households food insecure. 21 percent of its families must live without food for a day or moresomething Head warns its readers in her writing. Unfortunately, Botswana no longer offers agricultural sustainability to its people; it produces only $10 \%$ of its own food products for consumption and most of its governmental agency is allocated to diamond production and export.

Head's writing prefigures the collapse of traditional tribal economies in 1968. Her narrative provides a geographical space to examine the initial traumas that led to the ecologies of pain. Her ethnographic discourse establishes how pastoral economies were ghosted and devoured by intensive capitalist development that recruited traditional subsistence structures and undermined them by implementing cash crop and individual wage incentives. The implementation of modernized agricultural and mining technology by agribusiness and mining conglomerates devastated the collective relationship of subsistence farming, kinship systems, and cattle herding. In Head's narration, we see how women are "disproportionately" impacted by land and resource grabbing rendering female rural producers like Paulina the most vulnerable (Chu, 2011; Nixon, 2011; Kinoti, 2011). Head's narrative observations trace the gendered disequilibrium initiated by both the slow violence and "explosive-violence" of the landscape "testifying to the radically subjective, and thus generally uncommunicable, experience of pain" (Lionnet 137).

In 2021, it has become quite clear that Botswana must return to a sustainable approach of multi-crop production to maintain food sovereignty for its people. Multi-crop production for local consumption will protect Botswana from the insecurity of a fluctuating global market. As I have strongly argued, Bessie Head's writing offers a space for probing the slow violence and ecological genocide expedited by the trauma of agricultural development projects, which have separated humanity from nature and rendered 63 percent of the Tswana population food insecure. Head's warning to her readers is quite simple Golema Mmidi, "grow crops."

\section{DISCLOSURE STATEMENT}

No potential conflict of interest.

\section{REFERENCES}

[1] Achebe, Chinua. Things Fall Apart. Anchor Books, 1994.

[2] BehrMan, Julia, et al. The Gender Implications of LargeScale Land Deals. IFPRI Discussion Paper 01056, January 2011.

http://www.ifpri.org/sites/default/ files/publications/ifpridp01056.pdf

[3] Billingslea-Brown, Alma Jean. New Codes of Honor and Human Values in Bessie Head's 'When Rain Clouds Gather.' South Atlantic Review, Spring 2010, Vol. 75, No. 2.

[4] Caminero-Santangelo, Byron. "Different Shades of Green: Ecocriticism and African Literature." African Literature: An Anthology of Criticism and Theory. Ed. Tejumola Olaniyan and Ato Quayson. Malden, MA: Blackwell Publishing, 2007. 698-706.

[5] Carouth, Cathy. Unclaimed Experience: Trauma, Narrative and History. John Hopkins University Press, 1996.

[6] Chu, Jessica. Gender and 'Land Grabbing' in Sub-Saharan Africa: Women's land rights and customary land tenure. Development 54, 35-39 https://doi.org/10.1057/dev.2010.95

[7] Clay, Jason. World Agriculture and the Environment: A Commodity-By-Commodity Guide To Impacts And Practices. Island Press, 2004.

[8] Eldredge, Elizabeth A. "Women in Production: The Economic role of women in Nineteenth-Century Lesotho." Signs 16 (1991): 707-31.

[9] Fielding, Maureen. 2003 "Agriculture and Healing: Transforming Space, Transforming Trauma in Bessie Head's When Rain Clouds Gather."Critical Essays on Bessie Head, edited by Sample, Maxine. Praeger, 2003.

[10] Garrett, James M. "Writing Community: Bessie Head and the Politics of Narrative." Research in African Literatures, Vol. 30, no. 2, 1999, pp. 122-135.

[11] Glantz, Michael. H. "On the Interactions between Climate and Society." Population and Development Review 16, 1999, pp. 179-200.

[12] Gonzalez, Carmen G. "Trade Liberalization, Food Security, and the Environment: The Neoliberal Threat to Sustainable Rural Development," Transnational Law and Contemporary Problems 14, 2004, 419, 423, pp. 469-70.

[13] Head, Bessie. Question of Power. Longman, 2009.

[14] ___.Serowe: Village of the Rain Wind. Heinemann, 1981.

[15] ___. When Rain Clouds Gather. Oxford: Heinemann Educational, 1995. Print.

[16] Highfield, Jonathan. "Relations with Food, Agriculture, Colonialism, and Foodways in the Writing of Bessie Head." Under the Sign of Nature, edited by Bonnie Roos and Alex Hunt, University of Virginia Press, 2010. 
[17] Ibrahim, Huma. Bessie Head: Subversive Identities in Exile. University of Virginia Press, 1996.

[18] Iheka, Cajetan N. "Colo-Mentality: Colonial Trauma in Oyono's Houseboy and Condé's Crossing the Mangrove." Research in African Literatures, vol. 45, no. 4, 2014, pp. 33-49.

[19] Kinahan, John. "Fifteenth-century agropastoral responses to a disequilibrial ecosystem in southeastern Botswana." The Archeology of Drylands: Living at the margin,edited by Graeme Barker and David Gilbertson, Routledge, 2000.

[20] Kinoti, Kathambi. Africa's Latest Land Rush: The effect of Land Grabs on Women's Rights. AWID, 2012.

[21] Kipling, Rudyard. "The White Man's Burden: The United States \& The Philippine Islands, 1899." Rudyard Kipling's Verse: Definitive Edition, Doubleday, 1929.

[22] Lederer, Mary. In Conversation with Bessie Head. Bloomsbury Academic, 2019.

[23] _. Novels of Botswana in English, 1930-2006. African Heritage Press, 2014.

[24] Lionnet, Françoise. Geographies of Pain: Captive Bodies and Violent Acts in the Fictions of Myriam Warner-Vieyra, Gayl Jones, and Bessie Head. Callaloo, Vol. 16, No. 1, 1993, pp. 132-152.

[25] Loflin, Christine. African Horizons: The Landscapes of African Fiction. Greenwood Press, 1998.

[26] Mackenzie, Fiona. "Contested Ground: Colonial Narratives and the Kenyan Environment, 1920-1945." Journal of Southern African Studies 26, 2000, pp. 697 - 718.

[27] Maathai, Wangari. Unbowed: A Memoir. Knopf, 2006.

[28]__. The Challenge for Africa. Pantheon Books, 2009.

[29] _. .The Greenbelt Movement: Sharing the Approach and the Experience. Lantern Books, 2003.

[30] Margree, Victoria. "Wild Flowers: Bessie Head on Life, Health and Botany." Paragraph, vol. 27, no. 3, 2004, pp. 16-31.

[31] Merchant, Carolyn. Radial Ecology: The Search for a Livable World. Routledge, 2005.

[32] Murphy, Patrick. The Ecofeminist Subsistence Perspective Revisited in an Age of Land Grabs and its Representations

\footnotetext{
${ }^{\mathrm{i}}$ A protectorate were territories negotiated by treaty between the British and the dikgosi (the royal tribal leaders), the purpose of which was to preclude rival Boers and Germans from intervening in British interests. Under the protectorate, Britain was able to secure its own commercial interests by maintaining control while passing the administrative costs on to local leaders. The British Protectorate's land grabbing through land deals and manipulative concessions resulted in large populations being displaced along the eastern borders.

${ }^{i i}$ I use the term ecological apartheid to mean how a privileged few have been able to separate humanity from the bounty of nature's resources.

iii Head reports in Serowe: Village of the Rain Wind, how "Khama's introduction of the iron-hand plough" replaced the traditional hoe, which later became only used for weeding purposes and which a "clever white manufacturer" took out a patent on its design — one created by the Bathudi.
}

in Contemporary Literature. Feminismo/s 22, Diciembre 2013, pp. 205-224.

[33] Nazareth, Peter. "Path of Thunder: Meeting Bessie Head." Research in African Literatures. Vol. 37. No. 4, 2006, pp. 211-229.

[34] Nixon, Rob. Slow Violence and the Environmentalism of the Poor. Harvard University Press, 2011.

[35] Ogungbesan, Kolawole. "The Cape Gooseberry Also Grows in Botswana : Alienation and Commitment in the Writings of Bessie Head." Présence Africaine, no. 109, 1979, pp. 92-106.

[36] Perkins Marsh, George. Man and Nature: Physical Geography as Modified By Human Action (1864; rpt. Ann Arbor: University of Michigan Library, 2001), 27.

[37] Robin, Libby. "The Eco-humanities as Literature: A New Genre?” Australian Literary Studies 23, 2008, 290.

[38] Sample, Maxine. Critical Essays on Bessie Head. Praeger, 2003.

[39] Saro-Wiwa, Ken. A Month and a Day: A Detention Diary (London: Penguin, 1995).

[40] Shiva, Vandana.Making Peace with the Earth. Pluto Press, 2013.

[41] ___.Staying Alive: Women, Ecology, and Development. South End Press, 2010.

[42] __. Stolen Harvest: The Hijacking of the Global Food Supply. South End Press, 2000.

[43] Vatn, Arild. "The Environment as a Commodity." Environmental Values, vol. 9, no. 4, 2000, pp. 493-509.

[44] Vengroff, Richard. Botswana: Rural Development in the Shadow of Apartheid. Associated UP, 1977.

[45] Vigne, Randolph. A Gesture of Belonging: Letters from Bessie Head, 1965-1979. Heinemann, 1991.

[46] Vital, Anthony. "Toward an African Ecocriticism: Postcolonialism, Ecology, and Life and Times of Michael K." Research in African Literatures, 39: 1, 2008, pp. 87-106.

\section{Notes}

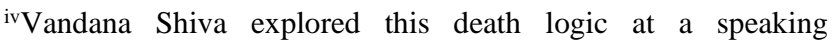
engagement in Berkeley, California on October 20, 2014, entitled "The Rights of Mother Earth."

" Some Head Scholars believe that Makhaya represents the voice of Bessie Head herself and her search for belonging.

vi Some critics believe that Makhaya's character blends attributes of Khama the Great who instituted many social reforms including the abolition of bogera, the discouragement of polygamy, witchcraft and rainmaking ceremonies (Head, Serowe 6).

vii 45-year old retired midwife Rosemary Pretorius recounts to Head a similar experience in which she was "accused of being the cause of stillbirths" (Serowe 136).

viii Peace Corps established their presence in Botswana from 1966 leaving in 1997 because of a growing economic sector. They returned in 2003 to provide service for the HIV/AIDS epidemic (THE PEACE CORPS | BOTSWANA WELCOME BOOK |2014, 7).

ix According to Tegegnework Gettu, Director of UNDP's Africa Bureau, "It is a harsh paradox that in a world of food surpluses, 
hunger and malnutrition remain pervasive on a continent with ample agricultural endowments" (Food security must be at center of Africa's development 15 May 2012).

x See Mathuba's "Review of the Tribal Land Act, Land Policies and Related Issues," 1989.

xi Head studied food production and "Tropical Agriculture" through a correspondence course according to her January 14, 1969 letter to Randolph. Her narrative is informed by these studies in western agricultural development (Vigne, Gesture of Belonging 70).

xii In Head's March 4, 1996 letter to Randolph from the Bamangwato Development Association, she writes of her experimental harvesting of tobacco for cash cropping (Vigne 28). xiii See Carmen G. Gonzalez, "Trade Liberalization, Food Security, and the Environment: the Neoliberal Threat to Sustainable Rural
Development," Transnational Law and Contemporary Problems 14 (2004): 419, 423, 469-70.419, 423, 469-70.

xiv Shiva's Staying Alive: The Hijacking of the Global Food Supply provides a detailed source for examining how cash cropping interferes with "staple-food production" (13).

$\mathrm{xv}$ While living on the experimental farm at Bamangwato Development Association, Head says she envisioned it as a place to "develop drought resistant seeds" (Vigne 47). 